\title{
atBRX1-1 and atBRX1-2 are involved in an alternative rRNA processing pathway in Arabidopsis thaliana
}

\author{
BENJAMIN L. WEIS, ${ }^{1}$ DENISE PALM, ${ }^{1}$ SANDRA MISSBACH, ${ }^{1,5}$ MARKUS T. BOHNSACK, ${ }^{1,2}$ \\ and ENRICO SCHLEIFF',3,4 \\ ${ }^{1}$ Department of Biosciences, Molecular Cell Biology of Plants, Goethe University, 60438 Frankfurt/Main, Germany \\ ${ }^{2}$ Institute for Molecular Biology, Georg-August University, 37073 Göttingen, Germany \\ ${ }^{3}$ Cluster of Excellence Frankfurt, Goethe University, 60438 Frankfurt/Main, Germany \\ ${ }^{4}$ Center of Membrane Proteomics, Goethe University, 60438 Frankfurt/Main, Germany
}

\begin{abstract}
Ribosome biogenesis is an essential process in all organisms. In eukaryotes, multiple ribosome biogenesis factors (RBFs) act in the processing of ribosomal (r)RNAs, assembly of ribosomal subunits and their export to the cytoplasm. We characterized two genes in Arabidopsis thaliana coding for orthologs of yeast BRX1, a protein involved in maturation of the large ribosomal subunit. Both atBRX1 proteins, encoded by AT3G15460 and AT1G52930, respectively, are mainly localized in the nucleolus and are ubiquitously expressed throughout plant development and in various tissues. Mutant plant lines for both factors show a delay in development and pointed leaves can be observed in the brx1-2 mutant, implying a link between ribosome biogenesis and plant development. In addition, the pre-rRNA processing is affected in both mutants. Analysis of the pre-rRNA intermediates revealed that early processing steps can occur either in the $5^{\prime}$ external transcribed spacer (ETS) or internal transcribed spacer 1 (ITS1). Interestingly, we also find that in xrn2 mutants, early processing events can be bypassed and removal of the $5^{\prime}$ ETS is initiated by cleavage at the $\mathbf{P}^{\prime}$ processing site. While the pathways of pre-rRNA processing are comparable to those of yeast and mammalian cells, the balance between the two processing pathways is different in plants. Furthermore, plant-specific steps such as an additional processing site in the $5^{\prime}$ ETS, likely post-transcriptional processing of the early cleavage sites and accumulation of a $5^{\prime}$ extended 5.8S rRNA not observed in other eukaryotes can be detected.
\end{abstract}

Keywords: rRNA processing; ribosome biogenesis; Brx1; Xrn2; Arabidopsis thaliana; 60S subunit maturation

\section{INTRODUCTION}

In eukaryotes, the mature $18 \mathrm{~S}, 5.8 \mathrm{~S}$, and $25 / 28 \mathrm{~S}$ rRNAs are transcribed as a single precursor rRNA by RNA polymerase I (Woolford and Baserga 2013; Henras et al. 2014). The mature rRNAs in this transcript are flanked by external transcribed spacers (ETS) and are separated by internal transcribed spacers (ITS). The 5S rRNA is transcribed separately by RNA polymerase III and is incorporated into 60S preribosomes during early ribosome assembly (Ciganda and Williams 2011). During and after transcription, the prerRNA is modified, processed, folded, and assembled with the ribosomal proteins (RP) (Watkins and Bohnsack 2012; Woolford and Baserga 2013; Turowski and Tollervey 2014). Pre-rRNA processing starts with the release of the primary transcript through an endonucleolytic cleavage in the $3^{\prime}$ ETS, performed by Rnt1 in yeast and atRTL2 in Arabidopsis thaliana (Kufel et al. 1999; Comella et al. 2008). In yeast,

\footnotetext{
${ }^{5}$ Present address: Sanofi-Aventis Deutschland GmbH, 65926 Frankfurt/ Main, Germany

Corresponding author: schleiff@bio.uni-frankfurt.de

Article published online ahead of print. Article and publication date are at http://www.rnajournal.org/cgi/doi/10.1261/rna.047563.114.
}

the $5^{\prime}$ ETS is first removed by cleavages at sites $A_{0}$ and $A_{1}$ performed by the SSU processome in the $90 \mathrm{~S}$ particle generating $33 \mathrm{~S}$ and 32S pre-rRNAs, respectively (Dragon et al. 2002; Osheim et al. 2004). Separation of the precursors of the small and large ribosome subunits (SSU and LSU, respectively) is primarily achieved by $\mathrm{A}_{2}$ cleavage in ITS1 that separates $90 \mathrm{~S}$ into pre-40S and pre-60S particles containing the $20 \mathrm{~S}$ and 27SA 2 pre-rRNAs (Bleichert et al. 2006; Henras et al. 2014). However, a minor pathway involving processing at a different cleavage site in ITS1, $\mathrm{A}_{3}$, is discussed (Henras et al. 2014). In contrast, in humans cells, most pre-rRNA transcripts are processed at site 2 in ITS1 (corresponding to site $\mathrm{A}_{3}$ in yeast) and this cleavage often occurs before removal of the $5^{\prime}$ ETS in human cells (Hadjiolova et al. 1993; Henras et al. 2014). Less is known about pre-rRNA processing in plants, but a processing scheme was recently described for

(C) 2015 Weis et al. This article is distributed exclusively by the RNA Society for the first 12 months after the full-issue publication date (see http:// rnajournal.cshlp.org/site/misc/terms.xhtml). After 12 months, it is available under a Creative Commons License (Attribution-NonCommercial 4.0 International), as described at http://creativecommons.org/licenses/by-nc/ $4.0 /$. 
A. thaliana. It was suggested, that cleavage at site $A_{3}$ is the first processing event following P-site cleavage in the $5^{\prime}$ ETS, which contains a specific insertion in Arabidopsis upstream of the P-site (Sáez-Vasquez et al. 2004; Zakrzewska-Placzek et al. 2010; Missbach et al. 2013; Weis et al. 2014), implying a processing pathway analogous to the major pathway in mammalian cells (Henras et al. 2014). However, an alternative processing route has also been suggested (Hang et al. 2014; Weis et al. 2014).

Pre-rRNA processing requires a multitude of proteinaceous and RNA RBFs (Woolford and Baserga 2013) and by genetic and proteomic studies $>200$ proteins functioning in ribosome assembly in yeast have been identified (for review, see Henras et al. 2008; Woolford and Baserga 2013). More recently inventories of RBFs have also been proposed for human cells (Wild et al. 2010; Tafforeau et al. 2013) and orthologs of $>200$ RBFs have been identified in plants (Xu et al. 2013; Ebersberger et al. 2014). However, the role of these putative RBFs in plant ribosome biogenesis still requires experimental confirmation, because the molecular functions of proteins may vary in different organisms. Indeed, we have recently shown that the orthologs of the yeast large ribosomal subunit GTPase 1 (Lsg1) (Kallstrom et al. 2003; Hedges et al. 2005) have diverged in its sequence and atLSG1-1 has lost its primary function in ribosome biogenesis, while atLSG1-2 still has its ancestral function in this process (Weis et al. 2014).

Another RBF involved in $60 \mathrm{~S}$ subunit biogenesis in yeast is "biogenesis of ribosomes in Xenopus 1" (Brx1). Brx1 belongs to the Imp4 superfamily and was first characterized in Xenopus laevis and yeast, where it was found to interact with rRNA and mutants affected pre-rRNA processing (Kaser et al. 2001). 35S, 27SA 2 , and the aberrant $23 \mathrm{~S}$ prerRNA accumulated after depletion of Brx1 in yeast (Kaser et al. 2001). The physical interaction of yeast Brxl with preribosomes was subsequently confirmed by pull down of the 66S preribosomal particles by TAP-tagged Rrp1 (Horsey et al. 2004). In addition, it was demonstrated that the anchoring of Brx1 to the preribosomal particle in yeast depends on Ebp2 (Shimoji et al. 2012), which in turn is essential for 25S rRNA maturation (Huber et al. 2000). Moreover, it was proposed that Tif6, Brx1, and Ebp2 are involved in the formation of the Rpf2 subcomplex, which plays a role in assembly of the central protuberance close to the top of the $60 \mathrm{~S}$ subunit (Talkish et al. 2012).

In A. thaliana, we discovered two orthologs to yeast Brx1. Both are ubiquitously expressed and are mainly localized in the nucleolus. Mutant plant lines for atBRX1-1 and atBRX1-2, brx1-1, and brx1-2, respectively, show developmental abnormalities and defects in pre-rRNA processing. Interestingly, we observed accumulation of a specific subset of pre-rRNAs in the $b r x 1$ mutant lines. We also reinvestigated the pre-rRNA processing pathway in $x r n 2$ mutant plants on our high-resolution agarose gels. These mutants show significant alterations in the pre-rRNA accumulation, while plant development remains unaffected (Zakrzewska-Placzek et al. 2010). Based on these data, we present a revised overview of pre-rRNA processing in A. thaliana and discuss it in comparison to the yeast and mammalian pathways. Our findings suggest that two alternative pre-rRNA processing pathways coexist in $A$. thaliana and that both the $\mathrm{A}_{2}$ and $\mathrm{A}_{3}$ cleavage sites in ITS1 are used to separate pre-40S and pre$60 \mathrm{~S}$ particles. Interestingly, mutation of the atBRX1 orthologs only affects one of these pathways.

\section{RESULTS}

\section{Two orthologs of Brx1 in A. thaliana are constitutively expressed}

Two orthologs of yeast Brx1 have been identified in A. thaliana (atBRX1-1, AT3G15460; atBRX1-2, AT1G52930). They share $41 \%$ and $40 \%$ sequence similarity with their yeast ortholog, respectively, and are themselves $86 \%$ similar in sequence. Both show the same architecture to the yeast protein but additionally possess a charged extension at the aminoterminus (Fig. 1A). This prompted us to investigate whether they are expressed in a tissue-specific manner. We isolated RNA from wild-type A. thaliana plants at different developmental stages and from different organs and analyzed the abundance of mRNAs coding for both orthologs by qRTPCR (Fig. 1B; Missbach et al. 2013; Weis et al. 2014). The abundance of the BRX1-1 mRNA was comparable in most tissues and only in roots and flowers of old plants, tissues with a higher demand for newly synthesized ribosomes, expression of the BRX1-2 mRNA appears to be enhanced (Fig. 1B). However, by statistical analysis this increase was not found to be significant.

Furthermore, we analyzed the presence of both atBRX1 proteins at different developmental stages and in different organs by Western blotting using an antibody generated against a mixture of full-length atBRX1-1 and atBRX1-2 (Fig. 1C). As a control, we analyzed the abundance of atRPL5 (Fig. 1C) using a specific antibody generated against full-length atRPL5. We found that both atBRX1 proteins are expressed in all analyzed tissues, but comparison to atRPL5 revealed a decline of atBRX1 abundance after day 18 in nonreproductive tissues like rosette, stem, and hypsophyll (Fig. 1C). Thus, the protein abundance in different tissues likely reflects the demand for ribosome biogenesis, as it is high in young developing tissues and reduced in leaves, stem, hypsophyll, and seeds, which are tissues with reduced rate of cell division. Interestingly, inspection of the coexpression analysis using String 9.1 (Franceschini et al. 2013) shows that both $B R X 1$ genes are coexpressed with genes that are orthologs of yeast RBFs (Table 1). Like Brx1, all these orthologs are involved in the maturation of $90 \mathrm{~S}$ and $60 \mathrm{~S}$ preribosomal complexes and at least Rpf2 and Has1 have also been found in the yeast complexes isolated by TAP-tagged Rrp1 (Horsey et al. 2004). 
A

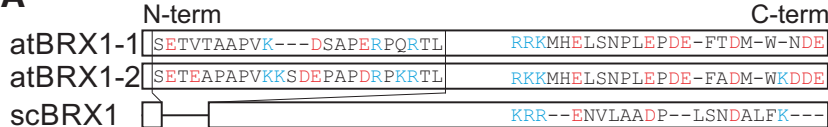

B

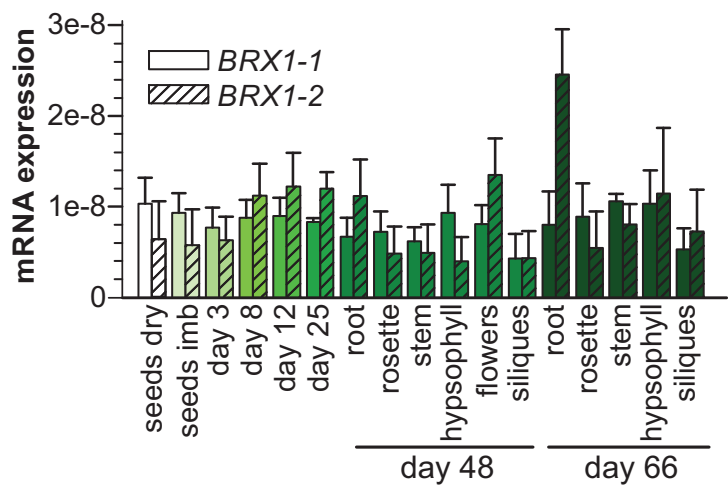

C

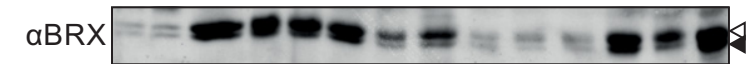

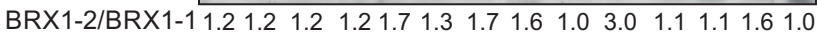

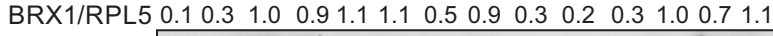

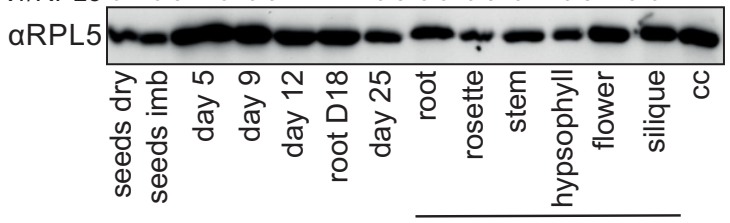

day 48

FIGURE 1. A. thaliana has two orthologs of the yeast ribosome biogenesis factor Brx1. (A) A schematic alignment of atBRX1-1, atBRX1-2, and scBRX1 is shown. Negatively and positively charged amino acids are colored in red and blue, respectively. Note that both atBRX1 proteins have a charged amino-terminal insertion. (B) The expression of BRX1-1 and BRX1-2 mRNAs at the indicated developmental stages was analyzed by qRT-PCR. The results are the mean of four independent biological replicates and standard deviation is shown. By $t$-test no change with $P$ $<0.05$ was observed. (Seeds imb) Imbibed seeds. $(C)$ Total proteins were extracted from the tissues and at the developmental stages indicated, separated on SDS-PAGE and subjected to Western blot using atBRX1 (top) and atRPL5 (bottom) antibodies. Arrowheads on the right indicate the migration of atBRX1-1 (filled) and atBRX1-2 (open). The intensity of detected bands was analyzed and the ratio of atBRX1-2 to atBRX1-1 and total atBRX1 to atRPL5, normalized to day 5, is indicated. (cc) Cell culture.

\section{Both atBRX1 proteins are nucleolar and associate with preribosomes}

Next, the subcellular localization of both atBRX1 proteins was analyzed. carboxyterminally GFP tagged atBRX1-1 and atBRX1-2 proteins were transiently overexpressed in protoplasts under the control of the $35 \mathrm{~S}$ promoter (Fig. 2A). Full-length fusion protein expression was confirmed by Western blotting using an anti-GFP antibody (Fig. 2A). atBRX1-1-GFP shows one band of the expected size, while atBRX1-2-GFP shows a double band suggesting that the protein expressed from this construct is partially unstable (Fig. $2 \mathrm{~A})$. Both proteins are mainly localized to the nucleolus as judged from the overlay of the GFP signal of atBRX1-GFP proteins and the fluorescence of Fibrillarin-mCherry as a nucleolar marker (Fig. 2A). These results are consistent with the nucleolar localization of yeast and mammalian BRX1 (Kaser et al. 2001).

The interaction of both atBRX1 proteins with ribosomes was studied using sucrose density gradient centrifugation (Fig. 2B). With the conditions used here, polysomes and $80 \mathrm{~S}$ ribosomes were unstable, but distinct peaks corresponding to fractions containing mature and pre-rRNAs, ribosomal proteins, and the RBF eIF6-2 clearly demonstrated the separation of the (pre-)40S and (pre-)60S particles (Fig. 2B). Interestingly, both atBRX1 proteins comigrate in the fractions corresponding to pre-60S complexes (Fig. 2B) suggesting that they are both involved in ribosome biogenesis.

\section{Individual BRX1 proteins are important for plant development}

We selected one SALK and one GABI-KAT transfer DNA (T-DNA) insertion line for $B R X 1-1$ and $B R X 1-2$, respectively (Fig. 3A), to further investigate the functions of both proteins in vivo. Screening PCRs on genomic DNA and sequencing analysis (Missbach et al. 2013) revealed a single back-toback T-DNA insertion in both lines, $b r x 1-1$ and $b r x 1-2$ (Fig. 3A,B). In addition, $b r x 1-1$ and $b r x 1-2$ are homozygous lines as the wild-type allele was no longer detectable (Fig. 3B, lanes 6 and 12, respectively). As expected, we detected a transcript upstream of the T-DNA insertion for both lines (Fig. 3C, first row of panels), but a full-length transcript was not detected in either plant line (Fig. 3C, third row of panels). However, in $b r x 1-2$ a transcript downstream from the insertion exists as well (Fig. 3C, lane 4, panel 2), likely caused by the $35 \mathrm{~S}$ promoter in the T-DNA close to the left border. Most important, the homozygosis of both lines was confirmed by Western blot using the atBRX1 antibody on protein extracts from wild-type and mutant flowers (Fig.

TABLE 1. Coexpression analysis with String 9.1

\begin{tabular}{|c|c|c|c|}
\hline Gene & STRING S $\mathrm{S}^{\mathrm{a}}$ & Yeast protein & Complex \\
\hline \multicolumn{4}{|c|}{ Coexpression analysis_-AT3G15460 (atBRX1-1) } \\
\hline AT4G04940 & 0.929 & UTP21 & $90 \mathrm{~S}$ \\
\hline AT5G52490 & 0.929 & FIBRILLARIN 2 & $90 \mathrm{~S}$ \\
\hline AT4G05410 & 0.928 & RRP9 & $90 S$ \\
\hline AT3G10530 & 0.928 & UTP7 & $90 \mathrm{~S}$ \\
\hline AT3G23620 & 0.925 & RPF2 & $60 \mathrm{~S}$ \\
\hline AT3G18600 & 0.922 & HAS1 & $90 \mathrm{~S}$ \\
\hline \multicolumn{4}{|c|}{ Coexpression analysis_AT1G52930 (atBRX1-2) } \\
\hline AT5C52490 & 0.980 & FIBRILLARIN 2 & $90 \mathrm{~S}$ \\
\hline AT1G31660 & 0.977 & ENP2 & $90 \mathrm{~S}$ \\
\hline AT5G08180 & 0.976 & NAN1 & $90 \mathrm{~S}$ \\
\hline AT3G23620 & 0.976 & RPF2 & $60 S$ \\
\hline AT4G12600 & 0.975 & SNU13 & $90 \mathrm{~S}$ \\
\hline AT2G40360 & 0.975 & ERB1 & $60 S$ \\
\hline
\end{tabular}



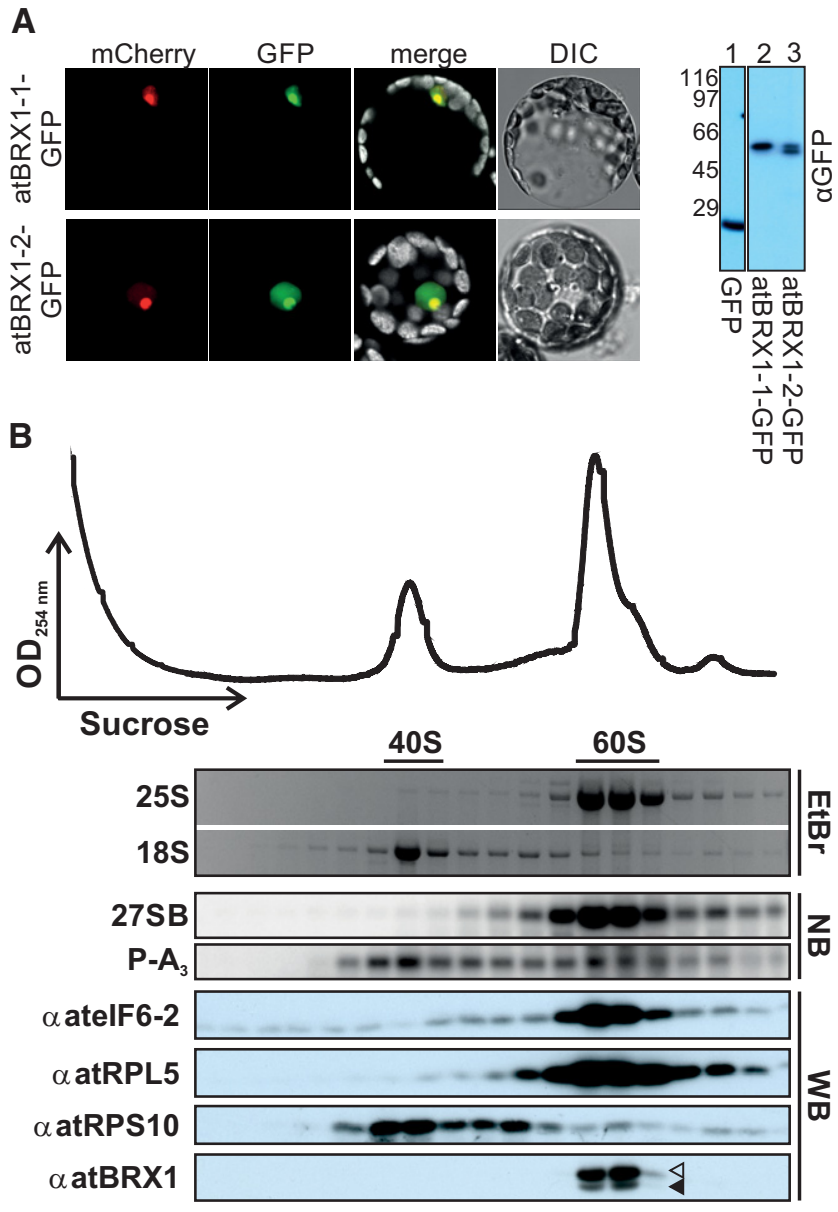

FIGURE 2. Both atBRX1 proteins are nucleolar and associated with pre-60S complexes. (A) A. thaliana protoplasts were cotransformed with plasmids coding for Fibrillarin-mCherry and either atBRX1-1GFP (top) or atBRX1-2-GFP (bottom). mCherry fluorescence (left) and GFP fluorescence (second panel) were merged with the autofluorescence of chlorophyll (third panel). A differential interference contrast (DIC) image is also shown (fourth panel). A representative image is given. Note that the nuclear signals may partially be due to overexpression of fusion proteins from the $35 \mathrm{~S}$ promoter. (Right) Transformed protoplasts were lysed and subjected to Western blot using a GFP antibody. (B) Sucrose density gradient centrifugation using total cell lysate from A. thaliana cell culture was performed. The UV absorption profile is shown on top. Mature rRNAs in the fractions were visualized by ethidium bromide $(\mathrm{EtBr})$ staining. Pre-rRNAs were detected by Northern blot (NB). Western blot (WB) analysis was carried out using the antibodies indicated on the left. Arrowheads indicate the migration of atBRX1-1 (filled) and atBRX1-2 (open).

3D). The corresponding full-length protein was not detected in brx1-1 and brx1-2, confirming that these lines are suitable to analyze the consequence of an absence of atBRX1-1 and atBRX1-2 in vivo. Nevertheless, atBRX1-1 accumulates slightly in the brx1-2 mutant (Fig. 3D) possibly to compensate for the loss of atBRX1-2. This suggests that both atBRX1 orthologs are redundant.

Next, we analyzed the phenotype of the two mutant lines. We observed a growth delay in both lines (Fig. 3E, inset) and an overall slower growth rate of brx1-2 (Fig. 3E). Further- more, development of the first rosette leaves was impaired in both lines (Fig. 3F), but was also more pronounced for brx1-2 (Fig. 3F). Interestingly, brx1-2 showed a slight pointed leaf phenotype (Fig. 3G) that has previously been observed in ribosomal proteins mutants (Byrne 2009; Horiguchi et al. 2011). Development of all following rosette leaves as well as flowering was also more delayed in $b r x 1-2$ than in $b r x 1-1$. However, crossing of both mutants did not lead to a double homozygous mutant (not shown), supporting that the atBRX1 orthologs are redundant.

\section{brx1 mutants affect pre-rRNA processing}

To gain insight into whether the atBRX1 proteins are required for rRNA processing, we isolated total RNA from wild-type, brx1-1 and brx1-2 seedlings, resolved it on highresolution agarose-glyoxal (Fig. 4B) or polyacrylamide gels (Fig. 4E) and detected pre-rRNAs by Northern blotting using a variety of probes hybridizing to different regions of the prerRNA transcripts (Zakrzewska-Placzek et al. 2010; Missbach et al. 2013; Weis et al. 2014). Importantly, probes annealing between each of the known/proposed cleavage sites in the pre-rRNA were used enabling each of the intermediate detected to be defined (Fig. 4A).

With all probes shown in Figure 4A, the 35S pre-rRNA, extending from site $\mathrm{P}$ in the $5^{\prime}$ ETS and extending into the

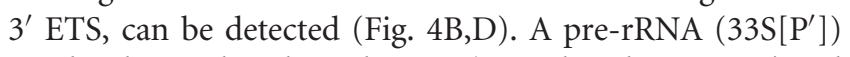
can be detected with probes $\mathrm{p} 2$ (annealing between $\mathrm{P}^{\prime}$ and the mature $5^{\prime}$ end of $18 \mathrm{~S}$ rRNA), p3, p42, p43, p4, and p5 (ITS2) but not with $\mathrm{p} 22$ (annealing between $\mathrm{P}_{1}$ and $\mathrm{P}^{\prime}$ ) or p6 ( $3^{\prime}$ ETS) (Fig. 4B,D). The $5^{\prime}$ end of $33 \mathrm{~S}\left(\mathrm{P}^{\prime}\right)$ is therefore generated by cleavage at site $\mathrm{P}^{\prime}$ and this precursor lacks the $3^{\prime}$ ETS. Although this intermediate has been observed previously (Zakrzewska-Placzek et al. 2010; Missbach et al. 2013; Weis et al. 2014), the processing steps/cleavage sites by which it is generated have remained unclear until now. Furthermore, $\mathrm{p} 3, \mathrm{p} 42, \mathrm{p} 43$, and $\mathrm{p} 5$ recognize the recently described $32 \mathrm{~S}$ pre-rRNA (Hang et al. 2014) that comigrates with $33 \mathrm{~S}\left(\mathrm{P}^{\prime}\right)$ under these conditions (Fig. 4B,D). We also observed the 27SA pre-rRNA with probes $\mathrm{p} 42$, p43 (between $\mathrm{A}_{2}$ and $\mathrm{A}_{3}$ ), and p5 (Fig. 4B,D). Interestingly, the $5^{\prime}$ end of this intermediate was previously thought to be generated by $\mathrm{A}_{3}$ cleavage; however, our data show that 27SA pre-rRNAs extending to $A_{2}$ $\left(27 \mathrm{SA}_{2}\right)$ can also be detected (see p42 and p43). In addition, the 27SB pre-rRNA was observed to accumulate significantly. This is also the case in yeast where it is proposed that downstream preribosomal remodeling steps are rate-limiting for pre-rRNA processing (Woolford and Baserga 2013). Furthermore, multiple $5^{\prime}$ extended precursors of the $18 \mathrm{~S}$ rRNA, named $\mathrm{P}-\mathrm{A}_{3}, \mathrm{P}^{\prime}-\mathrm{A}_{3}$ and $18 \mathrm{~S}-\mathrm{A}_{3}$, can be detected with probes p23, p22, p2, p3, p42, and p43 (Fig. 4B,D). The $3^{\prime}$ ends of all of these pre-rRNAs are extended to site $A_{3}$ because they are recognized by $\mathrm{p} 43$, which anneals immediately upstream of site $\mathrm{A}_{3}$. Interestingly, the $20 \mathrm{~S}$ precursor of the $18 \mathrm{~S}$ rRNA that extends from the $5^{\prime}$ end of $18 \mathrm{~S}$ to the $\mathrm{A}_{2}$ cleavage site and is 
A
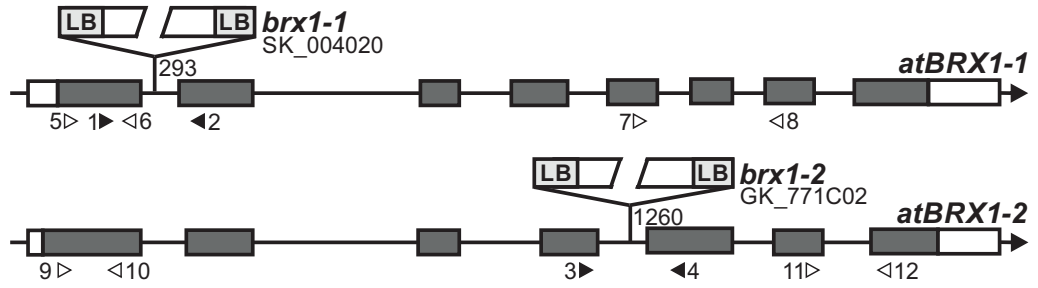

B
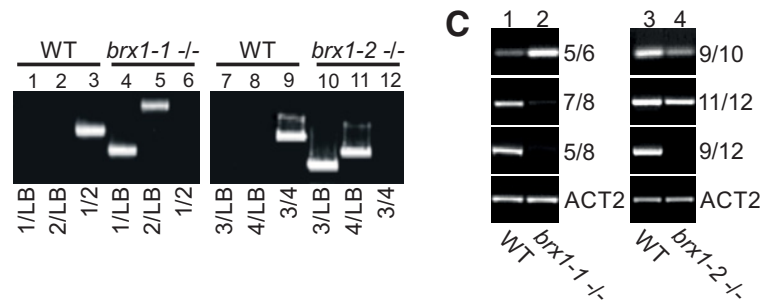

D

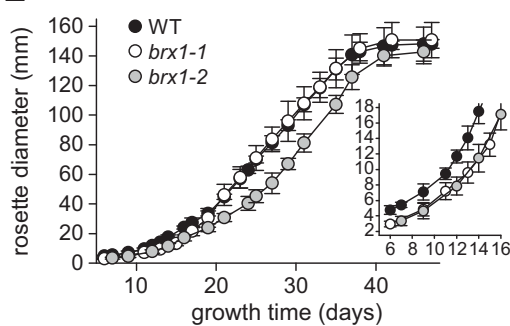

G

$\mathbf{F}$
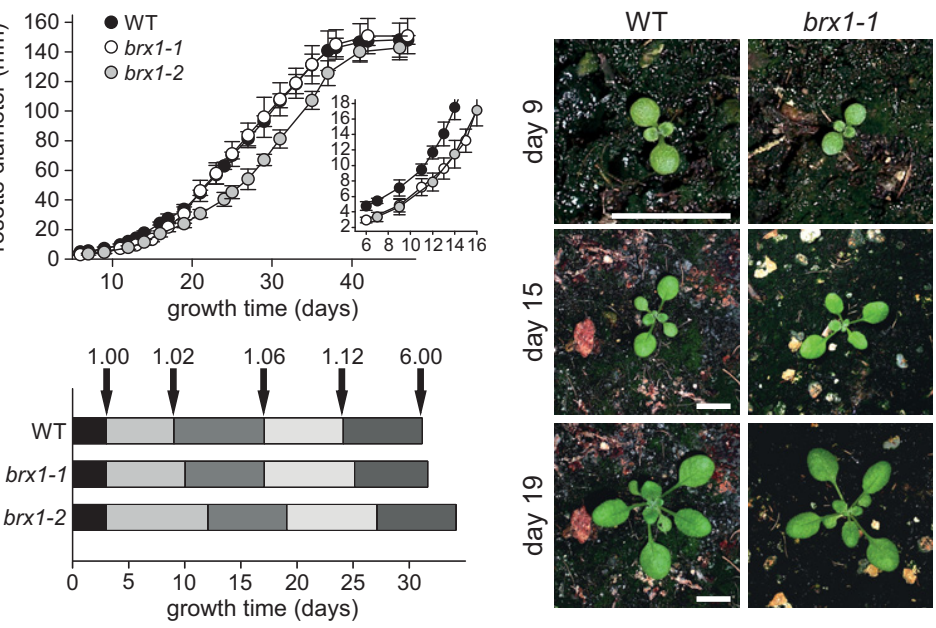

brx1-2

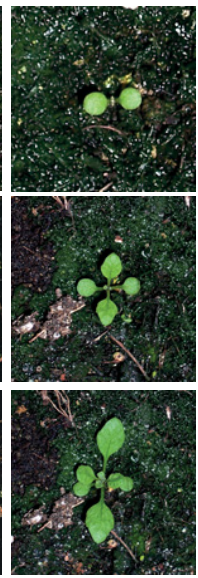

FIGURE 3. Characterization of $b r x 1$ mutant plants. $(A)$ The gene model of BRX1-1 and BRX1-2 with the T-DNA position of the mutants is shown. The positions of the oligonucleotides used in $B$ (filled triangle) and $C$ (open triangle) are indicated below. (B) The segregation of the T-DNA insertion in the indicated mutants (lanes 4-6 and 10-12) was analyzed by PCR on genomic DNA (gDNA) with the oligonucleotides shown in A. LB: T-DNA left border primer. Wild-type (WT) gDNA was analyzed as control (lanes 1-3 and 7-9). (C) The presence of BRX1 mRNA was analyzed by RT-PCR using RNA isolated from wild type (lanes 1,3), brx1-1 (lane 2), and brx1-2 (lane 4) and the oligonucleotides shown in A. Actin (ACT2) mRNA was amplified as loading control. $(D)$ The presence of the atBRX1 protein was determined by Western blotting using the atBRX1 antibody on protein extracts from wild type (WT, lane 1), brx1-1 (lane 2) and brx1-2 (lane 3). atRPL5 served as loading control (aRPL5). (E) The rosette diameter was determined for at least 10 independent, randomly selected, plants of each genotype as indicated. Inset shows the growth curve between days 4 and 16 . The standard deviation is shown. $(F)$ Developmental stages according to Boyes et al. (2001). (G) Pictures of the plant lines indicated on top were taken on days 9, 15, and 19. Scale bar: $10 \mathrm{~mm}$.

highly abundant in yeast, is not observed in A. thaliana wildtype seedlings. On the polyacrylamide gel, the conserved $3^{\prime}$ extended $5.8 \mathrm{~S}$ precursors $7 \mathrm{~S}$ and $6 \mathrm{~S}$ can be seen with probe p5 (Fig. 4E). In addition, a $5^{\prime}$ extended $5.8 \mathrm{~S}$ pre-rRNA containing the mature $3^{\prime}$ end of $5.8 \mathrm{~S}$ can be detected with $\mathrm{p} 4$.

All pre-rRNA intermediates described above were also detected in both brx1 mutants (Fig. 4B,E). The level of the $35 \mathrm{~S}$ pre-rRNA was unaltered in the mutants and was therefore used to determine the relative accumulations of other prerRNA species in the different lines (Fig. 4C). In both mutants, the $33 \mathrm{~S}\left(\mathrm{P}^{\prime}\right), 32 \mathrm{~S}$, and $27 \mathrm{SA}_{2}$ pre-rRNAs accumulated $\sim 2.5$-fold compared with wild type, while the levels of $\mathrm{P}-\mathrm{A}_{3}$ were reduced by half (Fig. 4B,C). Consistent with this, the ratio between $\mathrm{P}-\mathrm{A}_{3}$ and $32 \mathrm{~S}$ was five times lower than the ratio determined in wild type (Fig. 4C). The ratio between $27 \mathrm{SA}_{2}$ and $32 \mathrm{~S}$ was unaltered in the mutants (Fig. 4C). Interestingly, the $20 \mathrm{~S}$ pre-rRNA becomes visible in both brx 1 mutants, although at low levels (Fig. 4B). These results show that only a subset of the pre-rRNA intermediates are affected by mutation of BRX1 and support a function of both atBRX1 proteins in pre-60S subunit maturation in A. thaliana.

\section{Processing at site $\mathbf{P}$ can be bypassed}

The new insights into the cleavages in both the $5^{\prime}$ ETS and ITS1 that are used to generate pre-rRNA intermediates found 
in wild-type plants imply that rRNA maturation could be more complex than previously thought. To gain further information about these pathways we also examined plant lines lacking the exonuclease atXRN2 that have previously been shown to exhibit severe pre-rRNA processing defects (Zakrzewska-Placzek et al. 2010). atXRN2 is one of the three homologs for yeast nuclear $5^{\prime} \rightarrow 3^{\prime}$ exonuclease Rat1/Xrn2. In yeast, this protein is involved in the maturation of $5.8 \mathrm{~S}$ and 25 S rRNAs (Henry et al. 1994; Geerlings et al. 2000), in RNA decay (Bousquet-Antonelli et al. 2000), as well as in transcription termination (Kim et al. 2004; El Hage et al.
2008). Mammalian XRN2 has been shown to be required for pre-rRNA processing at site 01/A' (Wang and Pestov 2011; Sloan et al. 2014). xrn2 mutant plants do not show any visible phenotype, but accumulate $5^{\prime}$ extended rRNA precursors that have not been efficiently processed at site $\mathrm{P}$ (Fig. 5; Zakrzewska-Placzek et al. 2010). Furthermore, in $x r n 2 \mathrm{mu}-$ tant plants, $\mathrm{P}_{1}$ processing also appears to be impaired, because $5^{\prime}$ ETS degradation intermediates extending between site $\mathrm{P}$ and $\mathrm{P}^{\prime}$ accumulate in the mutant (Lange et al. 2011).

By Northern blot analysis, we observed a $5^{\prime}$ ETS extended $35 \mathrm{~S}$ and $\mathrm{P}-\mathrm{A}_{3}$ pre-rRNAs in the $x r n 2$ mutant $\left(35 \mathrm{~S}^{*}, 5^{\prime}\right.$ ETS-

A

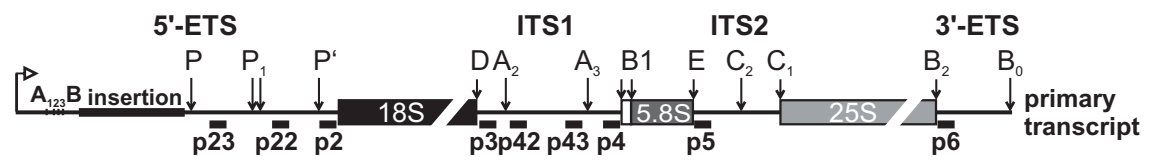

B
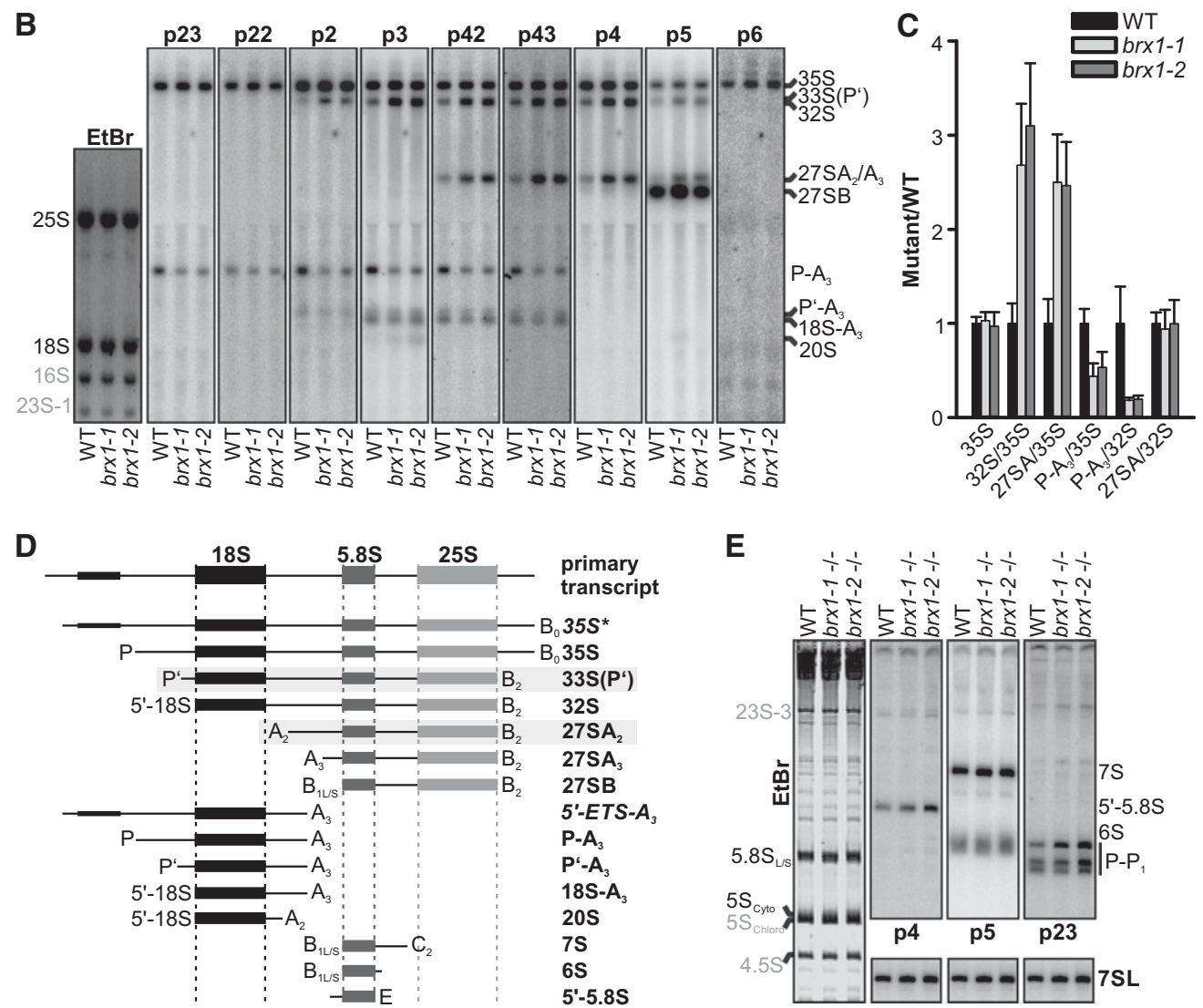

FIGURE 4. Accumulation of pre-rRNAs is affected in $b r x 1$ mutants. ( $A$ ) Shown is the primary pre-rRNA transcript of $A$. thaliana with the processing sites indicated by arrows on top. Probes ( $\mathrm{p}$ ) used for Northern blots are indicated below. Insertion: a 1083-nt sequence in the $5^{\prime}$ ETS specific for $A$. thaliana. (ETS) External transcribed spacer, (ITS) internal transcribed spacer. The $\mathrm{A}_{123} \mathrm{~B}$ cluster is specific to Brassicaceae and was shown to be bound by the NF-B/D complex important for P-site cleavage (Sáez-Vasquez et al. 2004). (B) Total RNA from 18-day-old seedlings from wild-type (WT) and the brxl mutants was separated on a 1.2\% agarose gel, transferred onto nylon membrane and hybridized with the probes indicated in A. Mature chloroplast rRNAs visible with ethidium bromide (EtBr) staining (23S-1 and 16S) are shown in gray. The names of the detected pre-rRNAs are given on the right. (C) Individual Northern blots as shown in $B$ were quantified and the band intensity was normalized to the $35 \mathrm{~S}$ pre-rRNA that is unaltered in the mutants. Wild-type values were set to one. $(D)$ Scheme of the pre-rRNAs that are detected in $B$. Light gray boxes mark the newly defined $33 S\left(\mathrm{P}^{\prime}\right)$ and $27 \mathrm{SA}_{2}$ pre-rRNAs. Italic: 5' extended pre-rRNAs seen in $x r n 2$ mutants (Fig. 5). (E) Total RNA from 18-day-old seedlings from wild-type (WT) and the brx 1 mutants was separated on an $8 \%$ acrylamide/ $8 \mathrm{M}$ urea gel, transferred onto nylon membrane and hybridized with the probes indicated. Mature chloroplast rRNAs seen by ethidium bromide (EtBr) staining (23S-3, 5S, and 4.5S) are shown in gray. The names of the detected pre-rRNAs are given on the right. 


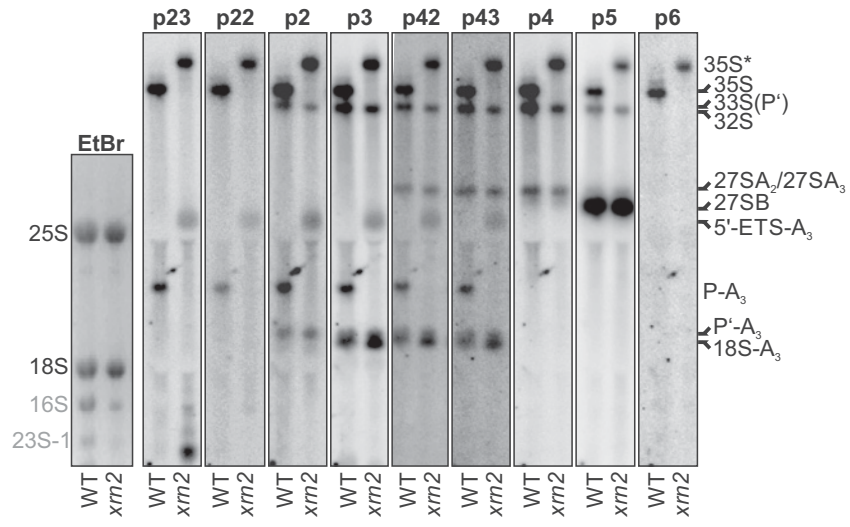

FIGURE 5. Processing at site P can be bypassed. Total RNA from wildtype (WT) and xrn2 mutant plants was analyzed as described in Figure $4 \mathrm{~B}$. The names of the pre-rRNAs detected are given on the right. Note that the $35 \mathrm{~S}$ and $\mathrm{P}-\mathrm{A}_{3}$ pre-rRNAs are $5^{\prime}$ ETS extended in the $x r n 2 \mathrm{mu}-$ $\operatorname{tant}\left(35 S^{*}\right.$ and $5^{\prime}$ ETS $-\mathrm{A}_{3}$, respectively).

$\mathrm{A}_{3}$ ) (Fig. 5), supporting the conclusion that atXRN2 is required for P-site cleavage and removal of an Arabidopsis-specific insertion in the $5^{\prime}$ ETS (Zakrzewska-Placzek et al. 2010). Interestingly, the $33 \mathrm{~S}\left(\mathrm{P}^{\prime}\right)$ and $\mathrm{P}^{\prime}-\mathrm{A}_{3}$ pre-rRNAs accumulated to normal levels in the $x r n 2$ mutant (Fig. 5), suggesting that P-site cleavage can be bypassed and downstream processing steps can occur normally leading to normal levels of the mature rRNAs. It is not clear whether cleavage of site $\mathrm{P}_{1}$ is a prerequisite for $\mathrm{P}^{\prime}$ processing as pre-rRNA intermediates specifically generated by this cleavage are not detectable, however, comparison to mammalian $5^{\prime}$ ETS processing might suggest that cleavage at $\mathrm{P}_{1}$ and $\mathrm{P}^{\prime}$ occur almost simultaneously as has been proposed for $A_{0}$ and $A_{1}$ (Henras et al. 2014). This suggests that the mature $5^{\prime}$ end of the $18 \mathrm{~S}$ rRNA can be generated even if early $5^{\prime}$ ETS processing is impaired.

\section{DISCUSSION}

\section{atBRX1 proteins are important for development}

Here, we identified and analyzed the two orthologs to the yeast RBF Brxl that is involved in early pre-60S maturation (Kaser et al. 2001; Horsey et al. 2004; Shimoji et al. 2012). Both atBRX1 proteins are highly similar in sequence (Fig. 1A), ubiquitously expressed (Fig. 1B,C), localize to the nucleolus (Fig. 2A) and, interestingly, both are associated with the pre-60S ribosomal subunit (Fig. 2B). Furthermore, plant lines lacking either one of the atBRX1 proteins show the same pre-rRNA processing defects and a double homozygous mutant is not viable (Figs. 3, 4). These results suggest that the two atBRX1 proteins have redundant function. In contrast, many other RBFs with multiple orthologs have diverged in their sequence or subcellular localization and only one of the orthologs still has its ancestral function in ribosome biogenesis (Pontvianne et al. 2007; Comella et al.
2008; Lange et al. 2008; Zakrzewska-Placzek et al. 2010; Durut et al. 2014; Weis et al. 2014).

Interestingly, the pointed leaf phenotype in brx1-2 (Fig. $3 \mathrm{G}$ ) was previously observed for many RP mutants (Byrne 2009; Horiguchi et al. 2011) and a delay in early growth and development was shown for multiple RBF mutants (Pontvianne et al. 2007; Lange et al. 2011; Weis et al. 2014). These observations imply that ribosome biogenesis, in general, is closely coupled to early plant development, likely due to the high demand for newly synthesized ribosomes in this growth phase.

\section{Pre-rRNA processing occurs by two alternative pathways in A. thaliana}

The observed pre-rRNAs in wild-type plants including the newly identified $33 \mathrm{~S}\left(\mathrm{P}^{\prime}\right)$ and $27 \mathrm{SA}_{2}$ pre-rRNAs (Fig. $4 \mathrm{~B}, \mathrm{D}$ ), as well as the accumulation of a defined set of pre-rRNAs in the brxl mutants (Fig. 4B,C), suggest two alternative rRNA processing pathways for A. thaliana (Fig. 6) as it was also proposed for the other eukaryotic model organisms (Woolford and Baserga 2013; Henras et al. 2014).

In "Pathway 1" (Fig. 6), the 35 S pre-rRNA is processed at the mature $3^{\prime}$ end of $25 \mathrm{~S}$ rRNA and at site $\mathrm{P}^{\prime}$ in the $5^{\prime} \mathrm{ETS}$, which yields the $33 \mathrm{~S}\left(\mathrm{P}^{\prime}\right)$ pre-rRNA (Fig. $\left.4 \mathrm{~B}\right) .33 \mathrm{~S}\left(\mathrm{P}^{\prime}\right)$ is then further processed to the $32 \mathrm{~S}$ pre-rRNA. These two steps resemble the $A_{0}$ and $A_{1}$ cleavages in yeast (Dragon et al. 2002; Phipps et al. 2011). Interestingly, the large pre-rRNAs (35S, $33 \mathrm{~S}$, and 32S) are barely detectable in yeast, because processing at sites $\mathrm{A}_{0}, \mathrm{~A}_{1}$, and $\mathrm{A}_{2}$ takes place cotranscriptionally on $>70 \%$ of all transcripts (Osheim et al. 2004; Koš and Tollervey 2010; Turowski and Tollervey 2014). In contrast, these pre-rRNAs can be well detected in A. thaliana (Figs. 4B, 5, Zakrzewska-Placzek et al. 2010; Missbach et al. 2013; Weis et al. 2014) suggesting that pre-rRNA processing mostly occurs post-transcriptionally under normal conditions as has been suggested for mammalian cells where 47S/45S, $43 \mathrm{~S}$, and $41 \mathrm{~S}$ can also be readily detected in wild type (Preti et al. 2013; Tafforeau et al. 2013; Sloan et al. 2014). Next, pre-40S and pre-60S maturation is separated by cleavage at $\mathrm{A}_{2}$ in ITS1 yielding the $20 \mathrm{~S}$ and $27 \mathrm{SA}_{2}$ pre-rRNAs. However, the $20 \mathrm{~S}$ pre-rRNA is barely detectable in wild type (Fig. $4 \mathrm{~B}$ ) suggesting rapid processing of this intermediate. In contrast, the yeast 20S pre-rRNA is readily detectable as it is part of the late pre-40S subunit that undergoes tight quality control in the cytoplasm (Lebaron et al. 2012; Strunk et al. 2012; García-Gómez et al. 2014). The $27 \mathrm{SA}_{2}$ pre-rRNA is further processed in a pathway similar to that used in yeast to generate the short and long forms of the $5.8 \mathrm{~S}$ rRNA $\left(5.8 \mathrm{~S}_{\mathrm{S}}\right.$ and $5.8 \mathrm{~S}_{\mathrm{L}}$, respectively) as well as the $25 \mathrm{~S}$ rRNA (Fig. 6). Interestingly, a $5^{\prime}$ extended $5.8 \mathrm{~S}$ pre-rRNA can be detected in wild type (Fig. 4E; Zakrzewska-Placzek et al. 2010; Missbach et al. 2013), suggesting that $3^{\prime}$ maturation of the 5.8S rRNA can naturally occur before maturation of the $5^{\prime}$ end, which is different to yeast or mammalian cells. In yeast, a $5^{\prime}$ 


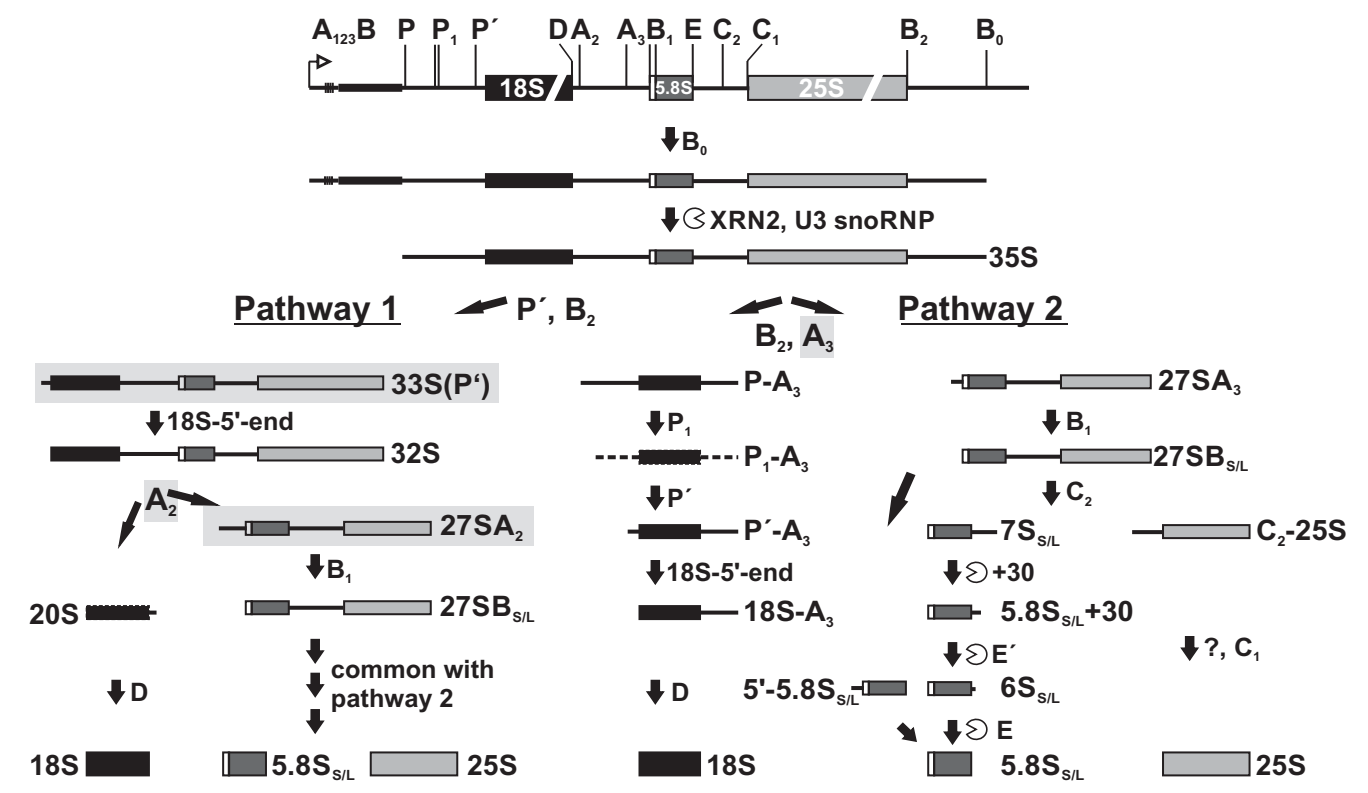

FIGURE 6. Two alternative rRNA processing pathways coexist in A. thaliana. A primary transcript is released by cleavage at site $\mathrm{B}_{0}$ mediated by atRTL2. Further processing involving the exonuclease atXRN2 and processing of the 1083-nt insertion prepares site P for efficient cleavage by the BoU3 snoRNP complex. (Left) In Pathway 1, the $35 \mathrm{~S}$ pre-rRNA is processed at site $\mathrm{P}^{\prime}\left(33 \mathrm{~S}\left[\mathrm{P}^{\prime}\right]\right)$ and subsequently at the mature $5^{\prime}$ end of $18 \mathrm{~S}$ rRNA (32S), before $\mathrm{A}_{2}$ cleavage releases the $20 \mathrm{~S}$ and $27 \mathrm{SA}_{2}$ pre-rRNAs. $20 \mathrm{~S}$ pre-rRNA is rapidly matured to the $18 \mathrm{~S}$ rRNA. (Right) Pathway 2 involves $\mathrm{A}_{3}$ cleavage to separate pre- $40 \mathrm{~S}$ and pre- $60 \mathrm{~S}$ particles. The resulting $\mathrm{P}-\mathrm{A}_{3}$ fragment is subsequently processed at $\mathrm{P}_{1}, \mathrm{P}^{\prime}$, and the mature $5^{\prime}$ end of $18 \mathrm{~S}$ pre-rRNA before the final processing step at site $\mathrm{D}$ occurs in the cytoplasm. $27 \mathrm{SA}_{2}$ (from Pathway 1 ) or $27 \mathrm{SA}_{3}$ (Pathway 2) are processed at site $\mathrm{B}_{1}$ before $\mathrm{C}_{2}$ processing separates them into $7 \mathrm{~S}$ and $\mathrm{C}_{2}-25 \mathrm{~S}$. The $7 \mathrm{~S}$ pre-rRNA likely undergoes $3^{\prime} \rightarrow 5^{\prime}$ exonucleolytic trimming that yields $5.8 \mathrm{~S}+30,6 \mathrm{~S}$, and finally the mature $5.8 \mathrm{~S}$ rRNA. Furthermore, a $5^{\prime}$ extended pre-5.8S rRNA is detectable in RNA from wild type, but its place in the processing scheme remains to be established. For further details and references see main text. Newly defined pre-rRNAs are marked by a gray box.

extended $5.8 \mathrm{~S}$ pre-rRNA is only detectable when factors such as Rat1 or Rrp17, that are directly involved in $5^{\prime}$ trimming of 5.8S rRNA precursors are deleted (Henry et al. 1994; Oeffinger et al. 2009). However, the relevance of this step for plant pre-rRNA processing, as well as its place in the presented processing scheme, is not yet clear (Fig. 6). Interestingly, the large pre-rRNAs belonging to the proposed Pathway 1 (33S $\left[\mathrm{P}^{\prime}\right], 32 \mathrm{~S}, 27 \mathrm{SA}_{2}$, and $20 \mathrm{~S}$ ) specifically accumulate in both brx1 mutants (Fig. 4B,C) supporting the conclusion that they belong to one processing pathway.

In "Pathway 2," the $35 \mathrm{~S}$ pre-rRNA is cleaved at site $\mathrm{A}_{3}$ to separate pre-40S and pre-60S maturation resulting in the $\mathrm{P}-\mathrm{A}_{3}$ pre-rRNA (comparable to $30 \mathrm{~S}$ in mammalian cells) and the $27 \mathrm{SA}_{3}$ pre-rRNAs (Fig. 6). The $\mathrm{P}-\mathrm{A}_{3}$ fragment is then processed to $\mathrm{P}^{\prime}-\mathrm{A}_{3}$ and $18 \mathrm{~S}-\mathrm{A}_{3}$ (Fig. 6). These fragments are comparable to the aberrant $23 \mathrm{~S}, 22 \mathrm{~S}$, and $21 \mathrm{~S}$ pre-rRNAs in yeast and $26 \mathrm{~S}$ and $21 \mathrm{~S}$ pre-rRNAs in mammalian cells (Henras et al. 2014). The $18 \mathrm{~S}-\mathrm{A}_{3}$ pre-rRNA is then cleaved at site $\mathrm{D}$ by the homolog of the endonuclease Nob1 (Fatica et al. 2003; Veith et al. 2012; Missbach et al. 2013). It remains unclear whether the $18 \mathrm{~S}-\mathrm{A}_{3}$ pre-rRNA is first processed to the $20 \mathrm{~S}$ pre-rRNA before $\mathrm{D}$-site cleavage or if atNOB1 can directly cleave the $18 \mathrm{~S}-\mathrm{A}_{3}$ pre-rRNA.

An alternative pre-rRNA processing route starting comparable to Pathway 1 was proposed in parallel by Hang and coworkers who described the $32 \mathrm{~S}$ pre-rRNA (Hang et al. 2014).
However, this proposed route would ultimately lead back to only one pathway in contrast to the two independent pathways described here as we have detected a $27 \mathrm{SA}_{2}$ pre-rRNA. In addition, we identified $33 \mathrm{~S}\left(\mathrm{P}^{\prime}\right)$ as the starting point for Pathway 1.

In conclusion, pre-rRNA processing in A. thaliana likely follows two alternative routes (Fig. 6). Pathway 1 is analogous to the main processing pathway used in yeast (Woolford and Baserga 2013; Henras et al. 2014) whereas Pathway 2 is comparable to the major processing pathway observed in mammalian cells (Mullineux and Lafontaine 2012; Henras et al. 2014). While the alternative ITS1 processing pathways have also been described for both yeast and mammalian cells, in these organisms the majority of transcripts are processed via a single pathway $\left(A_{2}\right.$ in yeast, $A_{3}$ like in mammals Woolford and Baserga 2013; Henras et al. 2014). Interestingly, both the $\mathrm{A}_{2}$ and the $\mathrm{A}_{3}$ processing sites are used in $A$. thaliana to separate the pre- $40 \mathrm{~S}$ and pre- $60 \mathrm{~S}$ particles (Fig. 6). Finally, in both pathways processing in the $5^{\prime}$ ETS can be bypassed by cleavage at site $\mathrm{P}^{\prime}$ as the newly identified $33 \mathrm{~S}\left(\mathrm{P}^{\prime}\right)$ and the $\mathrm{P}^{\prime}-\mathrm{A}_{3}$ fragments are detected in the $x r n 2$ mutants (Fig. 5). In future, it will be highly interesting to identify other factors required for ribosome maturation in A. thaliana and to investigate further the pathways of pre-rRNA processing and pre-rRNA intermediates that are specific for plants. 


\section{MATERIALS AND METHODS}

\section{In vivo localization}

For protein localization analysis, the coding sequences of atBRX1-1 and atBRX1-2 were amplified from cDNA and cloned into the pRTdS-vector (Missbach et al. 2013) to generate carboxy-terminal GFP fusions for expression in protoplasts. pRTdS-atFIB2-mCherry was used as a nucleolar marker (Missbach et al. 2013). A. thaliana leaf mesophyll protoplasts were isolated, transformed, and visualized as previously described (Sommer et al. 2011).
TABLE 2. Northern probes used in this study

\begin{tabular}{lll}
\hline Probe & $\begin{array}{c}\text { Position on pre-rRNA } \\
\text { (relative to TIS) }\end{array}$ & \multicolumn{1}{c}{ Sequence $\left(5^{\prime} \rightarrow 3^{\prime}\right)$} \\
\hline p23 & +1333 to +1356 & GTTCCAACTAATCTACCGAAGTAC \\
p22 & +1709 to +1732 & CTTTGGCGGGACTGAATCACTTCG \\
p2 & +1802 to +1824 & ACGGCAATTCCCCGCCACATCC \\
p3 & +3644 to +3668 & GGTCGTTCTGTTTTGGACAGGTATC \\
p42 & +3698 to +3722 & GCAAGGAATCGGCTAAGAAACCGGC \\
p43 & +3803 to +3826 & CACTTTTCGTGCCGGGGTTTTGTG \\
p4 & +3894 to +3915 & CGTTTTAGACTTCAGTTCGCAG \\
p5 & +4069 to +4093 & GGATGGTGAGGGACGACGATTTGTG \\
p6 & +7689 to +7718 & CGTTAAGGAGCTGTTGCTTTGTTAGTGTAG \\
7 SL & +2887 to +2908 & CGGAGTCCTATAAGCAACATCC \\
\hline
\end{tabular}

\section{Protein and antibody generation}

The coding sequences of atBRX1-1, atBRX1-2, atRPL5, and atRPS10 were amplified from cDNA and cloned into a modified pQE80 vector for amino-terminal fusion with a $\mathrm{His}_{21}$ tag. Proteins were expressed in BL21 star pRosetta cells for $4 \mathrm{~h}$ at $37^{\circ} \mathrm{C}$ with $0.25 \mathrm{mM}$ IPTG. All proteins were purified using NiNTA (Qiagen) under denaturing conditions in a buffer containing $25 \mathrm{mM}$ Tris $\mathrm{pH} 7.5$, $300 \mathrm{mM} \mathrm{NaCl}$, and $6 \mathrm{M}$ guanidium hydrochloride. The denatured atBRX1 proteins were mixed in a 1:1 molar ratio and used for antibody generation in rabbits (Dr. Pineda, Berlin). atRPL5 and atRPS10 were used to immunize one rabbit each. For antibody purification, the buffer of the atBRX1 proteins was exchanged to $0.1 \mathrm{M} \mathrm{NaHCO}_{3}$, $0.5 \mathrm{M} \mathrm{NaCl}$, and $8 \mathrm{M}$ urea for coupling to $\mathrm{CNBr}$ Sepharose. The atBRX1 matrix was then prepared and the antibody was purified according to the manufacturer's protocol (GE Healthcare). For Western blotting, the atBRX1 antibody was used in a 1:5000 dilution. For atRPL5 and atRPS10, the serum was used directly for Western blotting at a 1:20,000 dilution.

\section{Sucrose density gradient}

Sucrose density gradients were performed as described (Hsu et al. 2014) because we observed inefficient release of nucleolar preribosomes using our standard procedure (Missbach et al. 2013; Weis et al. 2014). Total cell lysate from A. thaliana cell culture was separated on a $10 \%-40 \%(\mathrm{w} / \mathrm{v})$ sucrose gradient by centrifugation for $18 \mathrm{~h}$ at $100,000 \mathrm{~g}$ in a TST41.14 rotor. Fractions were collected and analyzed as described previously (Weis et al. 2014).

\section{Reverse transcription and qRT-PCR analysis}

First strand cDNA from $1 \mu \mathrm{g}$ of RNA was synthesized using M-MuLV reverse transcriptase (Thermo Scientific) according to the manufacturer's protocol. The relative expression of BRX1-1 and $B R X 1-2$ mRNAs was quantified by qRT-PCR as previously described (Missbach et al. 2013).

\section{Protein analysis in different tissues and developmental stages}

For the analysis of the protein abundance of atBRX1-1 and atBRX12 in different developmental stages or different organs the tissue material was ground and directly resuspended in cracking buffer (5\% (w/v) SDS, $6 \mathrm{M}$ urea, $40 \mathrm{mM}$ Tris- $\mathrm{HCl} \mathrm{pH} \mathrm{6.8,} 0.1 \mathrm{mM}$ EDTA, $0.4 \mathrm{mg} / \mathrm{mL}$ bromophenol blue, $147 \mathrm{mM} \beta$-mercaptoethanol, $1 \mathrm{mM}$ PMSF). After incubation at $60^{\circ} \mathrm{C}$ for $10 \mathrm{~min}$ and centrifugation at $20,000 \mathrm{~g}$ for $5 \mathrm{~min}$ the supernatant was quantified using amido black protein quantification. Equal amounts of protein were loaded onto SDS-PAGE and subjected to Western blotting using the atBRX1 antibody. Western blots of biological replicates were quantified using ImageJ.

\section{Plant growth and T-DNA analysis}

The search for orthologs of scBrx1 was performed with In Paranoid (Ebersberger et al. 2014). T-DNA insertion lines for AT3G15460 (BRX1-1) and AT1G52930 (BRX1-2) were ordered from the Nottingham Arabidopsis Stock Centre (NASC; brx1-1: SALK_004020, brx1-2: GABI_771C02). Plants were grown in climate chambers under long day conditions ( $14 \mathrm{~h}$ photoperiod with $120 \mu \mathrm{mol} / \mathrm{m}^{2} / \mathrm{sec}$; $21^{\circ} \mathrm{C}$ at day and $18^{\circ} \mathrm{C}$ at night). Genomic DNA for screening PCRs was isolated as previously described (Edwards et al. 1991). T-DNA mapping was performed as previously described (Missbach et al. 2013). The T-DNA insertion mutants were further verified by reverse transcription (RT) PCR and Western blotting. For the latter, one flower was ground in $50 \mu \mathrm{L}$ cracking buffer using an EPPI-pestle before addition of another $100 \mu \mathrm{L}$ cracking buffer and incubation at $60^{\circ} \mathrm{C}$ for $10 \mathrm{~min}$. After centrifugation at $20,000 \mathrm{~g}$ for $5 \mathrm{~min}$, the supernatant (total protein) was analyzed by SDS-PAGE and Western blotting. Growth-stage based phenotypic analysis was performed as described (Boyes et al. 2001).

\section{RNA isolation and Northern blotting}

Total RNA from 18-d-old seedlings or flowers was isolated as previously described (Chomczynski and Sacchi 1987) with some modifications. Briefly, $100 \mathrm{mg}$ of tissue was frozen in liquid nitrogen and ground to a fine powder. Three milliliters of Solution D (4 M guanidine thiocyanate, $25 \mathrm{mM}$ sodium citrate $\mathrm{pH}$ 7.0, $147 \mathrm{mM} \beta$-mercaptoethanol, $0.5 \%(\mathrm{w} / \mathrm{v})$ sodium lauroyl sarcosinate) and $300 \mu \mathrm{L}$ of $2 \mathrm{M}$ sodium acetate $\mathrm{pH} 4.0$ were added and vigorously mixed. Three milliliters of acid saturated phenol (pH4.3, Sigma-Aldrich) and 600 $\mu \mathrm{L}$ chloroform were added, mixed, and incubated on ice for $15 \mathrm{~min}$. After centrifugation, the aqueous phase was extracted once with 
phenol:chloroform:isoamylalcohol (25:24:1) and once with chloroform, before precipitation with one volume isopropanol. RNA was pelleted, further purified using the NucleoSpin RNA kit (Macherey-Nagel) and eluted with $40 \mu \mathrm{L}$ RNase-free $\mathrm{H}_{2} \mathrm{O}$. Five micrograms of total RNA was resolved on a $1.2(\mathrm{w} / \mathrm{v}) \%$ agarose gel in BPTE buffer (30 mM Bis-Tris, $10 \mathrm{mM}$ PIPES, 1 mM EDTA) or on an $8 \%$ polyacrylamide/ $8 \mathrm{M}$ urea gel in TBE $(89 \mathrm{mM}$ Tris, $89 \mathrm{mM}$ boric acid, 2 mM EDTA) buffer before blotting on nylon $\mathrm{N}+$ membrane (GE healthcare). RNAs were cross-linked to the membrane using a Stratalinker and probed with ${ }^{32} \mathrm{P}$ end-labelled oligonucleotide probes as previously described (Missbach et al. 2013; Weis et al. 2014). The probes used are listed in Table 2.

\section{ACKNOWLEDGMENTS}

The A. thaliana cell culture was a kind gift from A. Batschauer (Marburg). We thank Sunny Sharma (Entian laboratory) for helping with gradient fractionation and stimulating discussions. This work was supported by the Deutsche Forschungsgemeinschaft in the frame of the SFB902/B8 (M.T.B.) and B9 (E.S.).

Received August 5, 2014; accepted December 8, 2014.

\section{REFERENCES}

Bleichert F, Granneman S, Osheim YN, Beyer AL, Baserga SJ. 2006. The PINc domain protein Utp24, a putative nuclease, is required for the early cleavage steps in 18 S rRNA maturation. Proc Natl Acad Sci 103: 9464-9469.

Bousquet-Antonelli C, Presutti C, Tollervey D. 2000. Identification of a regulated pathway for nuclear pre-mRNA turnover. Cell 102: $765-775$.

Boyes DC, Zayed AM, Ascenzi R, McCaskill AJ, Hoffman NE, Davis KR, Görlach J. 2001. Growth stage-based phenotypic analysis of Arabidopsis: a model for high throughput functional genomics in plants. Plant Cell 13: 1499-1510.

Byrne ME. 2009. A role for the ribosome in development. Trends Plant Sci 14: 512-519.

Chomczynski P, Sacchi N. 1987. Single-step method of RNA isolation by acid guanidinium thiocyanate-phenol-chloroform extraction. Anal Biochem 162: 156-159.

Ciganda M, Williams N. 2011. Eukaryotic 5S rRNA biogenesis. Wiley Interdiscip Rev RNA 2: 523-533.

Comella P, Pontvianne F, Lahmy S, Vignols F, Barbezier N, Debures A, Jobet E, Brugidou E, Echeverria M, Sáez-Vásquez J. 2008. Characterization of a ribonuclease III-like protein required for cleavage of the pre-rRNA in the $3^{\prime}$ ETS in Arabidopsis. Nucleic Acids Res 36: $1163-1175$.

Dragon F, Gallagher JE, Compagnone-Post PA, Mitchell BM, Porwancher KA, Wehner KA, Wormsley S, Settlage RE, Shabanowitz J, Osheim Y, et al. 2002. A large nucleolar U3 ribonucleoprotein required for $18 \mathrm{~S}$ ribosomal RNA biogenesis. Nature 417: 967-970.

Durut N, Abou-Ellail M, Pontvianne F, Das S, Kojima H, Ukai S, de Bures A, Comella P, Nidelet S, Rialle S, et al. 2014. A duplicated NUCLEOLIN gene with antagonistic activity is required for chromatin organization of silent $45 \mathrm{~S}$ rDNA in Arabidopsis. Plant Cell 26: $1330-1344$.

Ebersberger I, Simm S, Leisegang MS, Schmitzberger P, Mirus O, von Haeseler A, Bohnsack MT, Schleiff E. 2014. The evolution of the ribosome biogenesis pathway from a yeast perspective. Nucleic Acids Res 42: 1509-1523.

Edwards K, Johnstone C, Thompson C. 1991. A simple and rapid method for the preparation of plant genomic DNA for PCR analysis. Nucleic Acids Res 19: 1349.
El Hage A, Koper M, Kufel J, Tollervey D. 2008. Efficient termination of transcription by RNA polymerase I requires the $5^{\prime}$ exonuclease Rat1 in yeast. Genes Dev 22: 1069-1081.

Fatica A, Oeffinger M, Dlakić M, Tollervey D. 2003. Noblp is required for cleavage of the $3^{\prime}$ end of 18S rRNA. Mol Cell Biol 23: 1798-1807.

Franceschini A, Szklarczyk D, Frankild S, Kuhn M, Simonovic M, Roth A, Lin J, Minguez P, Bork P, von Mering C, et al. 2013. STRING v9.1: protein-protein interaction networks, with increased coverage and integration. Nucleic Acids Res 41: D808-D815.

García-Gómez JJ, Fernández-Pevida A, Lebaron S, Rosado IV, Tollervey D, Kressler D, de la Cruz J. 2014. Final pre-40S maturation depends on the functional integrity of the 60S subunit ribosomal protein L3. PLoS Genet 10: e1004205.

Geerlings TH, Vos JC, Raué HA. 2000. The final step in the formation of $25 \mathrm{~S}$ rRNA in Saccharomyces cerevisiae is performed by $5^{\prime} \rightarrow 3^{\prime}$ exonucleases. RNA 6: 1698-1703.

Hadjiolova KV, Nicoloso M, Mazan S, Hadjiolov AA, Bachellerie JP. 1993. Alternative pre-rRNA processing pathways in human cells and their alteration by cycloheximide inhibition of protein synthesis. Eur J Biochem 212: 211-215.

Hang R, Liu C, Ahmad A, Zhang Y, Lu F, Cao X. 2014. Arabidopsis protein arginine methyltransferase 3 is required for ribosome biogenesis by affecting precursor ribosomal RNA processing. Proc Natl Acad Sci 111: 16190-16195.

Hedges J, West M, Johnson AW. 2005. Release of the export adapter, Nmd3p, from the 60S ribosomal subunit requires Rpl10p and the cytoplasmic GTPase Lsg1p. EMBO J 24: 567-579.

Henras AK, Soudet J, Gérus M, Lebaron S, Caizergues-Ferrer M, Mougin A, Henry Y. 2008. The post-transcriptional steps of eukaryotic ribosome biogenesis. Cell Mol Life Sci 65: 2334-2359.

Henras AK, Plisson-Chastang C, O'Donohue MF, Chakraborty A, Gleizes PE. 2014. An overview of pre-ribosomal RNA processing in eukaryotes. Wiley Interdiscip Rev RNA doi: 10.1002/wrna.1269.

Henry Y, Wood H, Morrissey JP, Petfalski E, Kearsey S, Tollervey D. 1994. The $5^{\prime}$ end of yeast $5.8 \mathrm{~S}$ rRNA is generated by exonucleases from an upstream cleavage site. EMBO J 13: 2452-2463.

Horiguchi G, Mollá-Morales A, Pérez-Pérez JM, Kojima K, Robles P, Ponce MR, Micol JL, Tsukaya H. 2011. Differential contributions of ribosomal protein genes to Arabidopsis thaliana leaf development. Plant J 65: 724-736.

Horsey EW, Jakovljevic J, Miles TD, Harnpicharnchai P, Woolford JL Jr. 2004. Role of the yeast Rrpl protein in the dynamics of pre-ribosome maturation. RNA 10: 813-827.

Hsu YF, Chen YC, Hsiao YC, Wang BJ, Lin SY, Cheng WH, Jauh GY, Harada JJ, Wang CS. 2014. AtRH57, a DEAD-box RNA helicase, is involved in feedback inhibition of glucose-mediated abscisic acid accumulation during seedling development and additively affects preribosomal RNA processing with high glucose. Plant J 77: 119-135.

Huber MD, Dworet JH, Shire K, Frappier L, McAlear MA. 2000. The budding yeast homolog of the human EBNA1-binding protein 2 (Ebp2p) is an essential nucleolar protein required for pre-rRNA processing. J Biol Chem 275: 28764-28773.

Kallstrom G, Hedges J, Johnson A. 2003. The putative GTPases Nog1p and Lsg1p are required for $60 \mathrm{~S}$ ribosomal subunit biogenesis and are localized to the nucleus and cytoplasm, respectively. Mol Cell Biol 23: 4344-4355.

Kaser A, Bogengruber E, Hallegger M, Doppler E, Lepperdinger G, Jantsch M, Breitenbach M, Kreil G. 2001. Brix from Xenopus laevis and brxlp from yeast define a new family of proteins involved in the biogenesis of large ribosomal subunits. Biol Chem 382: 16371647.

Kim M, Krogan NJ, Vasiljeva L, Rando OJ, Nedea E, Greenblatt JF, Buratowski S. 2004. The yeast Ratl exonuclease promotes transcription termination by RNA polymerase II. Nature 432: 517-522.

Koš M, Tollervey D. 2010. Yeast pre-rRNA processing and modification occur cotranscriptionally. Mol Cell 37: 809-820.

Kufel J, Dichtl B, Tollervey D. 1999. Yeast Rnt1p is required for cleavage of the pre-ribosomal RNA in the $3^{\prime}$ ETS but not the 5' ETS. RNA 5: 909-917. 
Lange H, Holec S, Cognat V, Pieuchot L, Le Ret M, Canaday J, Gagliardi D. 2008. Degradation of a polyadenylated rRNA maturation by-product involves one of the three RRP6-like proteins in Arabidopsis thaliana. Mol Cell Biol 28: 3038-3044.

Lange H, Sement FM, Gagliardi D. 2011. MTR4, a putative RNA helicase and exosome co-factor, is required for proper rRNA biogenesis and development in Arabidopsis thaliana. Plant J 68: 51-63.

Lebaron S, Schneider C, van Nues RW, Swiatkowska A, Walsh D, Böttcher B, Granneman S, Watkins NJ, Tollervey D. 2012. Proofreading of pre-40S ribosome maturation by a translation initiation factor and 60S subunits. Nat Struct Mol Biol 19: 744-753.

Missbach S, Weis BL, Martin R, Simm S, Bohnsack MT, Schleiff E. 2013. $40 \mathrm{~S}$ ribosome biogenesis co-factors are essential for gametophyte and embryo development. PLoS One 8: e54084.

Mullineux ST, Lafontaine DL. 2012. Mapping the cleavage sites on mammalian pre-rRNAs: Where do we stand? Biochimie 94: $1521-1532$.

Oeffinger M, Zenklusen D, Ferguson A, Wei KE, El Hage A, Tollervey D, Chait BT, Singer RH, Rout MP. 2009. Rrp17p is a eukaryotic exonuclease required for $5^{\prime}$ end processing of pre-60S ribosomal RNA. $\mathrm{Mol}$ Cell 36: 768-781.

Osheim YN, French SL, Keck KM, Champion EA, Spasov K, Dragon F, Baserga SJ, Beyer AL. 2004. Pre-18S ribosomal RNA is structurally compacted into the SSU processome prior to being cleaved from nascent transcripts in Saccharomyces cerevisiae. Mol Cell 16: 943-954.

Phipps KR, Charette JM, Baserga SJ. 2011. The small subunit processome in ribosome biogenesis-progress and prospects. Wiley Interdiscip Rev RNA 2: 1-21.

Pontvianne F, Matía I, Douet J, Tourmente S, Medina FJ, Echeverria M, Sáez-Vásquez J. 2007. Characterization of AtNUC-L1 reveals a central role of nucleolin in nucleolus organization and silencing of AtNUC-L2 gene in Arabidopsis. Mol Biol Cell 18: 369-379.

Preti M, O'Donohue MF, Montel-Lehry N, Bortolin-Cavaillé ML, Choesmel V, Gleizes PE. 2013. Gradual processing of the ITS1 from the nucleolus to the cytoplasm during synthesis of the human 18S rRNA. Nucleic Acids Res 41: 4709-4723.

Sáez-Vasquez J, Caparros-Ruiz D, Barneche F, Echeverría M. 2004. A plant snoRNP complex containing snoRNAs, fibrillarin, and nucleolin-like proteins is competent for both rRNA gene binding and pre-rRNA processing in vitro. Mol Cell Biol 24: 72847297.

Shimoji K, Jakovljevic J, Tsuchihashi K, Umeki Y, Wan K, Kawasaki S, Talkish J, Woolford JL Jr, Mizuta K. 2012. Ebp2 and Brx1 function cooperatively in $60 \mathrm{~S}$ ribosomal subunit assembly in Saccharomyces cerevisiae. Nucleic Acids Res 40: 4574-4588.

Sloan KE, Bohnsack MT, Schneider C, Watkins NJ. 2014. The roles of SSU processome components and surveillance factors in the initial processing of human ribosomal RNA. RNA 20: $540-550$.

Sommer MS, Daum B, Gross LE, Weis BLM, Mirus O, Abram L, Maier U-G, Kühlbrandt W, Schleiff E. 2011. Chloroplast Omp85 proteins change orientation during evolution. Proc Natl Acad Sci 108: 13841-13846.

Strunk BS, Novak MN, Young CL, Karbstein K. 2012. A translation-like cycle is a quality control checkpoint for maturing $40 \mathrm{~S}$ ribosome subunits. Cell 150: 111-121.

Tafforeau L, Zorbas C, Langhendries JL, Mullineux ST, Stamatopoulou V, Mullier R, Wacheul L, Lafontaine DL. 2013. The complexity of human ribosome biogenesis revealed by systematic nucleolar screening of Pre-rRNA processing factors. Mol Cell 51: 539-551.

Talkish J, Zhang J, Jakovljevic J, Horsey EW, Woolford JL Jr. 2012. Hierarchical recruitment into nascent ribosomes of assembly factors required for 27SB pre-rRNA processing in Saccharomyces cerevisiae. Nucleic Acids Res 40: 8646-8661.

Turowski TW, Tollervey D. 2015. Cotranscriptional events in eukaryotic ribosome synthesis. Wiley Interdiscip Rev RNA 6: 129-139.

Veith T, Martin R, Wurm JP, Weis BL, Duchardt-Ferner E, Safferthal C, Hennig R, Mirus O, Bohnsack MT, Wöhnert J, et al. 2012. Structural and functional analysis of the archaeal endonuclease Nob1. Nucleic Acids Res 40: 3259-3274.

Wang M, Pestov DG. 2011. $5^{\prime}$-end surveillance by Xrn2 acts as a shared mechanism for mammalian pre-rRNA maturation and decay. Nucleic Acids Res 39: 1811-1822.

Watkins NJ, Bohnsack MT. 2012. The box C/D and H/ACA snoRNPs: key players in the modification, processing and the dynamic folding of ribosomal RNA. Wiley Interdiscip Rev RNA 3: 397-414.

Weis BL, Missbach S, Marzi J, Bohnsack MT, Schleiff E. 2014. The 60S associated ribosome biogenesis factor LSG1-2 is required for $40 \mathrm{~S}$ maturation in Arabidopsis thaliana. Plant J 80: 1043-1056.

Wild T, Horvath P, Wyler E, Widmann B, Badertscher L, Zemp I, Kozak K, Csucs G, Lund E, Kutay U. 2010. A protein inventory of human ribosome biogenesis reveals an essential function of exportin 5 in 60S subunit export. PLoS Biol 8: e1000522.

Woolford JL, Baserga SJ. 2013. Ribosome biogenesis in the yeast Saccharomyces cerevisiae. Genetics 195: 643-681.

Xu R, Zhang S, Huang J, Zheng C. 2013. Genome-wide comparative in silico analysis of the RNA helicase gene family in Zea mays and Glycine max: a comparison with Arabidopsis and Oryza sativa. PLoS One 8: e78982.

Zakrzewska-Placzek M, Souret FF, Sobczyk GJ, Green PJ, Kufel J. 2010. Arabidopsis thaliana XRN2 is required for primary cleavage in the pre-ribosomal RNA. Nucleic Acids Res 38: 4487-4502. 

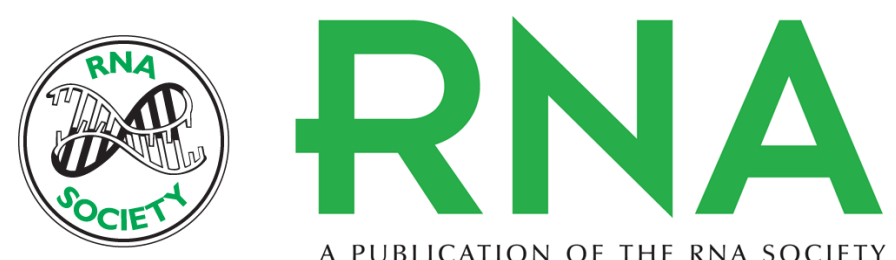

A PUBLICATION OF THE RNA SOCIETY

\section{atBRX1-1 and atBRX1-2 are involved in an alternative rRNA processing pathway in Arabidopsis thaliana}

Benjamin L. Weis, Denise Palm, Sandra Missbach, et al.

RNA 2015 21: 415-425 originally published online January 20, 2015

Access the most recent version at doi:10.1261/rna.047563.114

References This article cites 57 articles, 18 of which can be accessed free at: http://rnajournal.cshlp.org/content/21/3/415.full.html\#ref-list-1

Creative This article is distributed exclusively by the RNA Society for the first 12 months after the Commons full-issue publication date (see http://rnajournal.cshlp.org/site/misc/terms.xhtml). After 12 License months, it is available under a Creative Commons License (Attribution-NonCommercial 4.0 International), as described at http://creativecommons.org/licenses/by-nc/4.0/.

Email Alerting Receive free email alerts when new articles cite this article - sign up in the box at the Service top right corner of the article or click here.

To subscribe to $R N A$ go to:

http://rnajournal.cshlp.org/subscriptions 